\title{
Lancelot Threlkeld, Biraban, and the Colonial Bible in Australia
}

\author{
HILARY M. CAREY \\ University of Newcastle, New South Wales
}

Ethnographers, historians, and linguists have argued for many years about the nature of the relationship between missionaries and their collaborators. Critics of missionary linguistics and education have pointed out that Bible translations were tools forged for the cultural conquest of native people and that missionary impacts on local cultures nearly always destructive and frequently overwhelming (Comaroff and Comaroff 1997; Rafael 1988; Sanneh 1989). Sociolinguistic readings of scripture translation have emphasized the cultural loss inherent in the act of translation and even seemingly benign activities such as dictionary making (Errington 2001; Peterson 1999; Tomlinson 2006). To make this point, Rafael (1988: xvii) notes the semantic links between the various Spanish words for conquest (conquista), conversion (conversión), and translation (traducción). Historians, on the other hand, have generally been more skeptical about the power of mere words to exert hegemonic pressure on colonized people and have emphasized the more tangible power of guns and commerce as agents of empire (Porter 2004). Few would deny the symbolic power of the Bible as a representation of colonial domination, as in the saying attributed to Archbishop Desmond Tutu by Cox (2008: 4): "When the white man arrived, he had the Bible and we had the land; now, we have the Bible and he has the land."

One of the most contentious issues has proven to be the issue of indigenous agency in relation to the translation of the Bible. For devout Protestants, the possession of the Bible was - and is - assumed to be inherently liberating.

Acknowledgments: I thank the Australian Research Council for funding research visits to consult the London Missionary Society archives in the School of Oriental and African Studies, London, the British and Foreign Bible Library in Cambridge University Library, and the Sir George Grey collection in Auckland City Library. Thanks also to Edward James for photography. An early version of this paper was presented at the first meeting of the Australian Society for the History of Pacific Linguistics, Australian National University, Canberra, on 1 August 2008. I am indebted to the CSSH referees for their painstaking comments that helped deepen my interpretation. The deficiencies are my own. 
They argue that, freed from the trammels of the Roman Catholic Church and the restrictions it placed on access to the Word in their own language, the Bible alone enables believers to nourish a personal relationship with their Savior. Yet while parts of the Bible offer important narratives of liberation and exodus, Prior (1997: 39) argues that the discourse in which a covenanted people receive entitlement to land provided effective justification for settler colonialism and the displacement of indigenous peoples in Latin America, South Africa, and Palestine as well as Australia and Ireland. Such views are echoed by Sugirtharajah $(2002 ; 2005)$, who suggests that the English Bible was unavoidably colonialist even when submitted to translation. Yet not everyone sees the Bible as such an all-powerful colonial tool. Gardner (2006a; 2006b) suggests that Bible translation in parts of the Pacific was a means for cultural mediation as much as appropriation of indigenous culture, and Sanneh (2001) has robustly defended the old thesis of the liberating power of the gospel in relation to southern Africa, stressing that the production of vernacular scriptures and the introduction of literacy and printing led to numerous unanticipated repercussions which missionaries rarely had the capacity to control. Rather than colonial hegemony, he sees native agency and autonomy as features of the translation movement, suggesting that Africans came to possess their translated scriptures "like the ancient Israelites the promised land" (2001: 30). Larson similarly stresses the variety of uses to which missionary languages might be put, in his account of the Malagasy language that was the vehicle for the African diaspora of the Indian Ocean (2009). In Australia, McDonald (2001) has argued that modern Pentecostalism in northern Australia demonstrates the Aboriginal capacity to mine the Old Testament as a liberating narrative for marginalized desert people.

In the nineteenth century, Protestant missionaries had few doubts about the power of the Bible to win souls; naively, they believed that once the barrier of language was broken the Word alone would wash away heathendom and vice and raise up truth and colonial knowledge in its place (Smalley 1991; Hovdhaugen 1996). As Thorne $(1997 ; 1999 ; 2006)$ and Johnson $(2001 ; 2003)$ have argued, one of the primary means by which the evangelical missionary efforts were forwarded was through their mastery of imperial print cultures. Throughout the colonial period, missionary and Bible societies were subsumed into a vast publication machine that involved hundreds of societies, auxiliaries, and committees churning out annual reports, sermons, journals, and tracts. ${ }^{1}$ At the apex of this textual mountain stood the Bible, in the numberless languages of the world, produced through countless hours by an army of field missionaries

\footnotetext{
1 For the scale of British missionary publications, see Cox (2008: 115-16). The Missionary Periodicals Database hosted by the Yale University Divinity School Library has about six hundred separate missionary titles published in Britain from early in the eighteenth century to 1960. The larger societies distributed these in tens of thousands of copies.
} 
and their, generally nameless, native collaborators, and disseminated by organizations such as the British and Foreign Bible Society (1804), the American Bible Society (1816) and their many subsidiary societies and auxiliaries. ${ }^{2}$ In the library of Bible House in London, the headquarters of the British and Foreign Bible Society, there was a memorial window which enshrined the great scripture translators in world history: Jerome, Cyril and Methodius, William Tyndale, John Elliot, William Carey, Robert Morrison, Henry Martyn, and Robert Moffat. ${ }^{3}$ As this suggests, the most prestigious translators were those who translated the gospel into languages with the most numerous potential converts to Christianity, or who were first in the field. These were the chief Apostles of the Word. Yet there is a notable omission from the world map of these translator pioneers, namely a figure to represent the continent of Australia and the surrounding Pacific region with its numerous small, diverse, and largely tribal populations and their languages.

This essay provides an intimate history of one attempt to create a Bible on the remote reaches of the Australian frontier; it concerns a working partnership which fused to create it, and the power of the book which long outlived its creators. Like many similar efforts to translate the Bible into minor languages, it was a failure in the terms understood by mission societies of the day: it produced no conversions, supported no ongoing Christian community, and did not appear in print until the language concerned had become extinct. What this study reveals is something new, for despite the inadequacies of the translation effort, the hostility and violence of the frontier in which the translation work proceeded, and the despair and death of those who created it, it generated a unique colonial artifact which has its own history and which prospered after the collapse of the mission and the passing of the colonial frontier.

\section{THRELKELD, BIRABAN, AND THE HRLM LANGUAGE}

Lancelot Threlkeld (1788-1859), apothecary, actor, missionary, linguist, humanitarian, coal developer, postal reformer, and Congregational minister, has presented many faces to scholars attracted to his life, personality, and work. Gunson (1974)

2 Up to 31 December 1853, the British and Foreign Bible Society (Canton 1904, v. 2: 469-70) claimed to have printed 16,8887,181 English Bibles, New Testaments, and portions of scripture; 8,424,289 in continental European languages; and 542,304 in Asiatic languages and lesser numbers in other world languages. Stoll (1982) reviews the debate about the imperial impact of scripture translation in Latin America.

${ }^{3}$ The Old Testament was originally written in Hebrew; the New Testament in koiné ("Common") Greek. The window, installed in the Bible House Library in 1911, represents, in chronological order: translators of the Bible into Latin: Jerome (c. 340-347); Old Church Slavonic: Cyril (fl. 869) and Methodius (fl. 885); English: William Tyndale (1536); Algonquin, Massachusetts: John Eliot (c. 1604-1690); Bengali, Sanskrit, Marathi, Hindi: William Carey (17611834); Chinese: Robert Morrison (1782-1834); Urdu, Persian, and Arabic: Henry Martyn (1781-1812); and Setswana: Robert Moffat (1795-1883). The window is recalled by Moffat's biographer Smith (1925: 245), as cited by Sanneh (2001: 37). 
has published a major biographical study with an edition of his missionary and ethnographic writings, and there are others by Champion (1939) and Johnson (2006). Historians have scrutinized his missionary efforts on behalf of the London Missionary Society (LMS), and later the government of New South Wales, as well as the linguistic work on which they collaborated (Carey 2004; Johnston 2003; Roberts 2008). Reynolds (1998: 60-69) was more impressed by Threlkeld's humane defense of Aborigines in both the courts and the press, reporting with moral passion on the escalating violence of the expanding colonial frontier. From a different perspective, Johnston (2001; 2003) has seen Threlkeld's missionary writing as characterized by the cultural biases and rhetorical tropes typical of the genre, and elsewhere (2006) has discussed him as a representative of those imperial adventurers whose careers crossed the globe. These biographical and linguistic studies are the foundation for what follows, but scholars to date have had less to say about the project that Threlkeld likely considered the culmination of his life's work, namely the scripture translations which he completed in a number of stages between 1829 and 1859.

Threlkeld's chief collaborator on the latter project was an Aboriginal man known originally as Johnny McGill or We-pong, and later as Biraban (c. 1800-d. 1846). ${ }^{4}$ Gunson $(1967 ; 1974: 6-7)$ and Roberts $(2002 ; 2008)$ summarize what is known about his life. Biraban was taken to Sydney when he was a boy and brought up as a servant in the household of an officer. As a result, he spoke excellent English, which helped him maintain a livelihood as a guide, interpreter, and bush-constable. In 1821, he served with Captain Francis Allman at Port Macquarie north of Newcastle, during which time he tracked and apprehended runaway convicts. In about 1833 he returned to Lake Macquarie where he was recognized as "chief" and may have undergone ceremonial initiation during which he took on a new name, Birabān ("eagle hawk"). On 27 April 1836, Biraban guided Quaker visitors James Backhouse and George Washington

\footnotetext{
4 For Biraban's various names, age, and local standing we are reliant on Threlkeld's returns to the colonial government on Aborigines living around Lake Macquarie (Gunson 1974: 360-70). In the return for 21 May 1828, "M'gill" is listed with the Aboriginal name "We-pohng," and another man, Jemmy Jackass or "We-rah-kah-tah," whose wife is said to be "insane at Port Macquarie," is said to be "King of the District." At this stage, Threlkeld lists twenty-four men, twenty-six women, and fourteen children, sixty-four in all, among the "Black Natives belonging to Lake Macquarie and Newcastle." In 1833, however, when blankets were issued at Lake Macquarie, "McGill," whose native name is not given, is now called "chief" of the Lake Macquarie people. There is also a "Little McGill" listed among the children. In 1835, only "Young McGill," whose native name is Ninnoai and whose probable age is given as sixteen, makes an appearance. McGill, whose native name is now given for the first time as "Birabān," is listed with a probable age of forty. $\mathrm{He}$ is still there in 1836 and in 1838 both the "Old" and "Young McGill" are present. At this date, "Old McGill" is given an estimated age of thirty, and "Young McGill," whose native name has now also changed to "Birabān," are both present. In 1840, McGill Senior (Birabān) is said to be thirty-eight, and Little McGill (Birabān) is said to be twenty. They do not appear again. The date of Biraban's death appears as 1842 in the Australian Dictionary of Biography (Gunson 1966). However, this is incorrect, since his obituary shows he died in April 1846 (Sydney Morning Herald, 1 May 1846).
} 
Walker the twenty-six miles from Newcastle to Threlkeld's Ebenezer mission at Lake Macquarie (see Map 1). Backhouse noted that McGill was a great smoker and "had contracted a debasing appetite for strong drink" (1843: 379). The fullest account of Biraban is Threlkeld's posthumous tribute to him which is included as part of the preface to Threlkeld's revised Australian Grammar (1850): “An aboriginal of this part of the colony was my daily companion for many years, and to his intelligence I am principally indebted for much of my knowledge respecting the structure of the language." This remarkable declaration is best understood in the light of Threlkeld's need to demonstrate the scientific validity of his work as a translator, despite the loss of most of the language community before the bulk of his researches could be published. ${ }^{5}$ For the same reason, a portrait of Biraban was prominently displayed in the edition of the Grammar (1850), published in time for the Great Exhibition of 1851, and was also inserted in the fine copy of the Gospel of St. Luke that Threlkeld made for Sir George Grey (1857). ${ }^{6}$ Threlkeld and his supporters frequently commented on Biraban's prepossessing appearance, his intelligence, and his gift for teaching language. In his 1850 tribute, Threlkeld cites the report of Biraban made by Horatio Hale (1817-1896), the philologist of the United States Exploring Expedition, who paid a visit to the mission in 1839 and supplied an account of the languages he encountered (Hale 1846). "It was very evident," Hale noted, "that McGill was accustomed to teach his native language, for when he was asked the name of anything he pronounced the word very distinctly, syllable by syllable, so that it was impossible to mistake it" (Wilkes 1845: 253). But in a passage not cited by Threlkeld, Hale also reported that, although he was aware of the doctrines of Christianity and the comforts of civilization, Biraban remained attached to his traditional beliefs and, "He was always a prominent leader in their corrobories and other assemblies" (ibid.: 254). He was also active as a warrior defending the mission site against assaults from bushrangers and the inter-tribal and inter-personal violence which infested the region of the mission; he personally defended Threlkeld's young son Joseph, then aged eleven, when he was threatened by one of the mission's convict servants (Gunson 1974: 99). Sir William Edward Parry (1790-1855), the Arctic explorer and Director of the Australian Agricultural Company from 1829 until 1834, was another visitor who encountered Biraban at Lake Macquarie. He noted in his journal of 13 October 1830 that McGill was Threlkeld's "very intelligent Instructor," but also that he was not tied to the mission and regularly left to manage his own affairs (ibid.: 113). What seems to be the last report of Biraban is

\footnotetext{
5 The British and Foreign Bible Society Bible Society advised that all new translations should be prepared by committees, and seldom agreed to publication of translations that were prepared by single translators or revisers. Translators were also warned to choose a "central language" when commencing translations, so as not to waste Society money publishing in minor dialects (Bliss 1891: 401).

6 This portrait of Biraban was drawn by the artist of the American Exploring Expedition in 1838 and published with their report (Wilkes 1845: 254).
} 


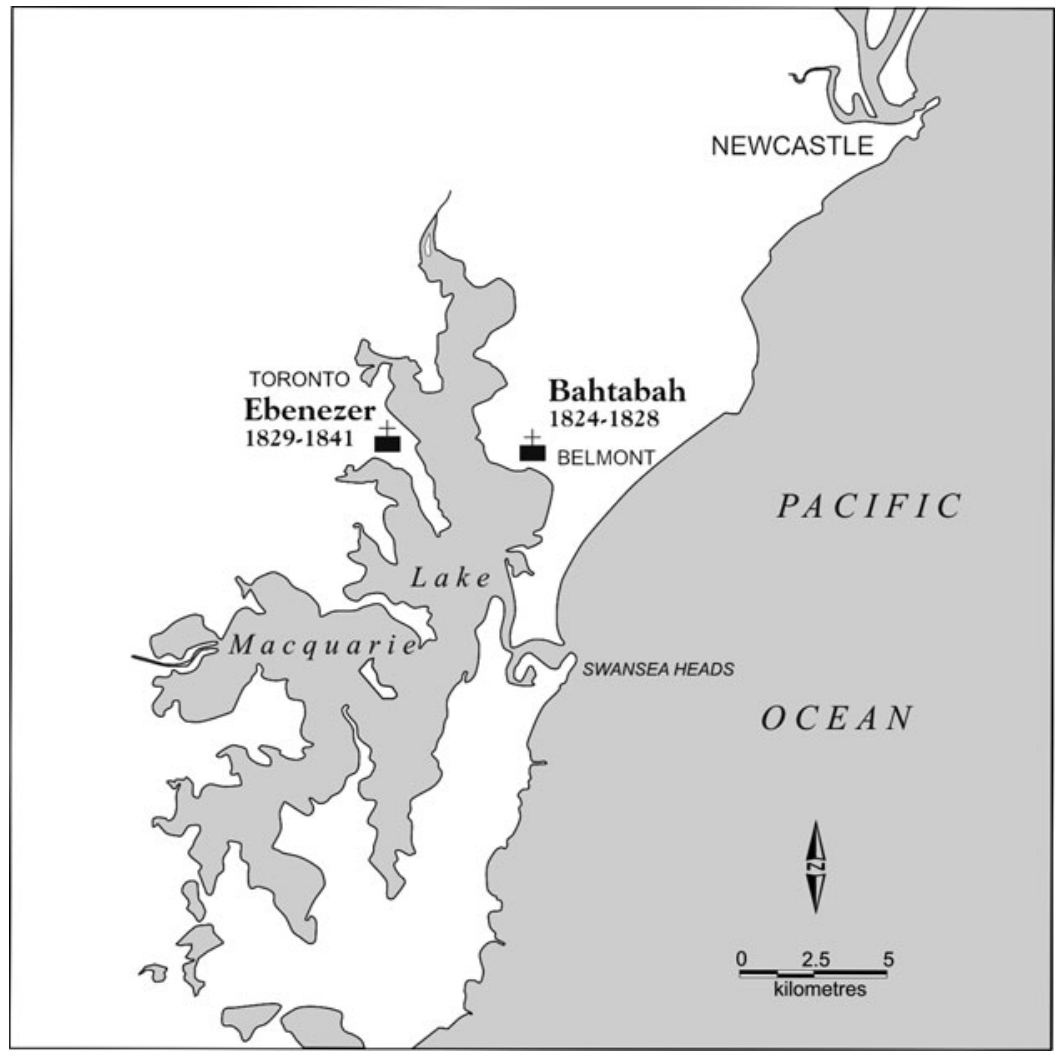

MAP 1 Locations of Threlkeld's first and second missions on Lake Macquarie ("Awaba”), New South Wales.

from October 1842, when the Prussian explorer, Ludwig Leichhardt describes an encounter with "John McGill, king of the Lake Macquarie clan," whom he describes as a "noble savage" (ibid.: 7).

Taken together, these reports suggest that Biraban was a skilled intermediary between Europeans and Aborigines, that he had an extensive network of contacts along the coast from Port Macquarie to Sydney, that he maintained a rich ceremonial life, and that he knew how to dance, fight, and shoot. He was clearly not dependent on Threlkeld for his subsistence or self-esteem. His relationship with Threlkeld was nevertheless significant in securing an important marker of his status in colonial society. In 1830, Governor Darling honored him with a breastplate bearing the inscription: "Barabahn, or MacGil, Chief of the Tribe at Bartabah, on Lake Macquarie; a Reward for his assistance in reducing his Native Tongue to a written Language" (Sydney Gazette 12 Jan. 1830). The 
bestowing of breastplates was a practice initiated by Governor Lachlan Macquarie in an attempt to do something to improve interracial relations (Cleary 1993). "Chiefs" or "Kings" were those granted higher status and rights of negotiation on behalf of particular clans or tribes. In April 1836, Backhouse and Walker noticed that Biraban was still wearing his breastplate with some pride (1843: 379), but the shine appears to have worn off. Three years later, Hale observed that although these honorifics were at first highly valued, they did not reflect natural distinctions of status and that at the time of his visit to the mission they were held in disrepute (1846: 255).

What were the imperial forces that brought Threlkeld and Biraban together at the LMS mission at Lake Macquarie? Why, despite the most adverse circumstances, did they choose to invest so much intellectual effort in translating scripture into the obscure language of a rapidly diminishing people at what was then the remote periphery of the earth? The explanation lies in events that occurred well beyond the Australian colony of New South Wales, and had their roots in the history of missionary linguistics and European colonialism. Since the time of the Spanish humanist Antonio de Nebrija (1444-1522), who described language as compañera del imperio ("the companion of empire”) (Rafael 1988: 23, citing González-Llubera 1926: Prólogo), missionaries have recognized a symbiotic relationship between linguistics and colonial power. After Nebrija, French, Spanish, and Portuguese Catholic missionaries created grammars and word lists and translations for the peoples whom they encountered in the course of their colonization of the Americas and Asia (Hanzelli 1969; Koerner 2004; Zwartjes 2004). In the succeeding age of Protestant imperialism, new emphasis was given to the work of scripture translation. Like their Catholic predecessors, Protestant missionary linguists saw themselves as apostles and evangelists bringing the Word to new peoples. In the British Empire, the traditional spur to this phase of Protestant mission effort is usually said to have been the publication in 1792 of William Carey's manifesto on behalf of those who "have neither Bible nor written language" (2004b: 5). Organizations that worked to meet the textual need Carey identified included the British Society for Promoting Christian Knowledge (SPCK) and the British and Foreign Bible Society (Batalden, Cann, and Dean 2004). Together, they aimed to provide physical copies of the Word of God for all people, whatever their language, class, race, or creed.

Although Threlkeld had many peers in other mission fields, his persistence in acquiring an Aboriginal language in Australia and using it for scripture translation was unprecedented and remained so for generations after his death in 1859. The 1891 Encyclopedia of Missions includes a lengthy article on scripture translation, with an appended list compiled by R. W. Cust of the Church Missionary Society and British and Foreign Bible Society, of 269 Bible versions by language and geographic area (Bliss 1891: 573). Australia's contribution is stated in a single word: "nothing." This reveals ignorance of Threlkeld's then unpublished 
translations of the Gospel of St. Luke (1831, rev. 1857) and St. Mark (1837), but seventy-five years later scripture translations into Australian languages were still rare. In 1963, the Bible Society catalogued its holdings of scripture translations in the languages of Australia, New Zealand, and the main island groups of the North and South Pacific (Dance 1963). Of the 712 printed scripture translations no more than four were listed from Australia, the earliest being Threlkeld's 1857 revised translation of the Gospel of St. Luke, edited by John Fraser (1891). Fraser had sent one copy to the LMS and provided another to the Bible Society, explaining in a 28 May 1892 letter that the work was "quite unique and likely to continue to be so." This was no more than the truth. According to Ferguson (1987), the first complete translation of the Bible into an Aboriginal language was mainly the achievement of three linguist ethnographers of the Lutheran missions of Central Australia: John Flierl, J. G. Reuther, and Carl F. T. Strehlow. Not until 1896 did Reuther, working at the Bethesda Mission, complete their collaborative translation of the Old and New Testaments into Diyari (Churches 2002).

While missionary linguists today maintain their traditional status as pioneers of the gospel (albeit to a smaller circle of admirers in these more secular times), their standing has been lower in the eyes of post-colonial scholars, whose critique of scripture translation and missionary linguistics has been unremitting since the 1980s. For theorists such as Fabian (1983: 83; 1986; 1990), Rafael (1988), and Pennycook (1998), missionary linguistics was essentially a work of appropriation in which native languages were seen as debased and in need of purification and grammatical order so as to refine them into fitting vehicles for the word of God. Errington (2001) relegates missionaries to fellow travelers who secured the imposition of European linguistic hegemony throughout the colonized world. In Australia, Van Toorn has considered the relationship between Biraban and Threlkeld in a study of Aboriginal writing. She does not classify the extensive body of grammatical writing or scripture translation generated by Threlkeld as authored by Biraban. Instead, she pursues the chimera of the unmediated native voice, speculating that Biraban should be recognized as a visionary, artist, and spiritual leader (2006: 47), largely on the basis of two highly speculative sources, neither written by Biraban. The first is Threlkeld's account of a dream recounted to him by Biraban in 1836 (Gunson 1974: 134), which happens to be narrated in the first person. The second is a painting of a spirit being, known as the "Milbrodale Baiami," which has no known connection with Biraban, or indeed with the spirit being known as Baiami, who is not attested anywhere in coastal New South Wales. ${ }^{7}$ Biraban's dream is an important source of information about syncretistic beliefs emerging in the context of missionary teaching, but Biraban and

\footnotetext{
${ }^{7}$ For the popular cult of Baiame, see Carey (1998). For the debate about colonial impacts on southeastern sky god cults, including those associated with Baiame, see Swain (1993), and Hiatt (1996).
} 
Threlkeld's mutual entanglement as authors was much more productive, creative, and extensive than this.

As part of a wider historical revision of missionary writing, more sympathetic interpretations are emerging as historians and linguistic anthropologists turn their attention to colonial linguistic texts, a domain previously dominated by linguists. Peterson (1999) and Gilmour (2004; 2006; 2007) have pioneered a more nuanced investigation of the circumstances in which missionaries created frontier grammars, dictionaries, and scripture translations. Pennycook (1998) has investigated the ways in which English displaced majority languages in imperial cities such as Hong Kong, and missionary linguistics continues to expand beyond its antiquarian origins in other colonial contexts. In the Pacific, Tomlinson (2006; 2009) has worked to tease out the shifts of meaning in Fijian words such as mana ("effectiveness") and dina ("to tell the truth") that were chosen to represent Christian concepts and rituals. While these studies recognize the role played by language in the colonial process, they have shown more sympathy to the circumstances in which missionaries were obliged to create their linguistic expertise and publications, and appreciation of their works' value as what are often the only records of languages now extinct. However, there has been relatively little comparable work done on Australian sources with the important exception of the studies recently edited and authored by McGregor (2008a; 2008b).

Before considering Threlkeld and Biraban's scripture translations, an initial difficulty arises with the name of the language they were working on. Threlkeld did not seem to know of one and it is possible, as Hale suggested (1846: 482), that this was because it had no Aboriginal name. In the titles of his books, Threlkeld's usual practice was to designate it by a simple toponymic label: "a Dialect of the Aborigines of New South Wales" (1827), or "the Language as Spoken by the Aborigines, in the Vicinity of Hunter's River, Lake Macquarie, \&c. New South Wales" (1834a; 1836). Perhaps to make it sound more exotic, Threlkeld's editor (Frazer 1892: Preface, v), who had never heard a native speaker use the language, called it "Awabakal" after the Hunter River and Lake Macquarie (HRLM) name for Lake Macquarie (Awaba). However toponymics, while common in English, are less so in Aboriginal languages. With rather more cause, therefore, on his pioneering language map of Australia Schmidt (1919) labeled the language Kuri (the HRLM term for "man" or "mankind"), which corresponds to the territories of the extensive coastal nation mapped by Fraser (1892: frontispiece, viii) as that of the Kuringgai. ${ }^{8}$ In modern times, Fraser's "Awabakal" has caught on both as a popular contemporary designation of the Hunter Valley and Lake Macquarie Aboriginal peoples and as a term modern linguists use for the language. Dixon updated

\footnotetext{
${ }^{8}$ See Map 2, based on "Map of New South Wales as Occupied by Native Tribes, prepared by Dr Fraser" (1892: frontispiece).
} 
Fraser's orthography to create something that corresponds to modern linguistic conventions for Aboriginal words: "Awabagal" (2002). In a break with what had become an unthinking convention, Lissarrague (2006) has reverted to Threlkeld's usage, naming it "the language from the Hunter River and Lake Macquarie."9 This usage is followed here.

By whatever name we choose to call it, HRLM did not long survive European colonization of Australia's eastern seaboard: Threlkeld states that it was all but extinct by about 1850 (1850: Preface). Yet it was once spoken by Aboriginal people who now identify as Awabakal, Ku-ring-gai, and Wonnarua, whose country stretched north of Sydney along the coast from Port Jackson to Port Stephens, and inland along the Hunter River and all its tributaries as far as the ranges (Lissarrague 2006: 12-14). It was one of approximately 250 languages spoken in Australia at the time of European settlement of which only about half survive in some form today. But it does have a unique status: it was the first Aboriginal language to be described in any detail and it was the one selected for the only significant Bible translations completed in the colonial period.

\section{LINGUISTICS IN THE CONTACT ZONE}

While Threlkeld's scripture translations were the product of his continuous life's work, they were undertaken in two distinct phases that correspond to the two locations for the mission itself on opposite sides of Lake Macquarie. The first phase began with the establishment of the LMS mission at "Bahtahbah" (now Bataba) from 1824-1828; the second with Threlkeld's dismissal by the LMS and his decision begin a second, government-funded mission at "Ebenezer" (1829-1841) on a site granted by the colonial government on the other side of Lake Macquarie. ${ }^{10}$ Unlike earlier attempts to civilize and educate the Aborigines in New South Wales, such as the Blacktown Native Institution (Brook and Kohen 1991), which was conducted in English, the main innovation of Threlkeld's missions stems from his determination to acquire and use the native language. In a 23 April 1825 letter to the Rev. George Burder, Secretary of the LMS, he announced: "My first employment will be to obtain the Language of the Aborigines without which it would be a mere farce to attempt anything under the name of a Missionary establishment" (Gunson 1974: 181).

\footnotetext{
9 Lissarrague (2006: 13-14) also notes the existence of a Hunter Valley people now known as Geawegal, a name consisting of the HRLM word for "no" (kayaway) and the "belonging" suffix (-al), who probably spoke HRLM. On the model of other Aboriginal languages named and identified by their word for "no," Geawegal could serve as a name for the HRLM language, which had the benefit of being attested in its region by indigenous speakers of the language.

${ }_{10}$ Threlkeld was dismissed largely because the LMS thought he was making unreasonable financial demands on the Society.
} 


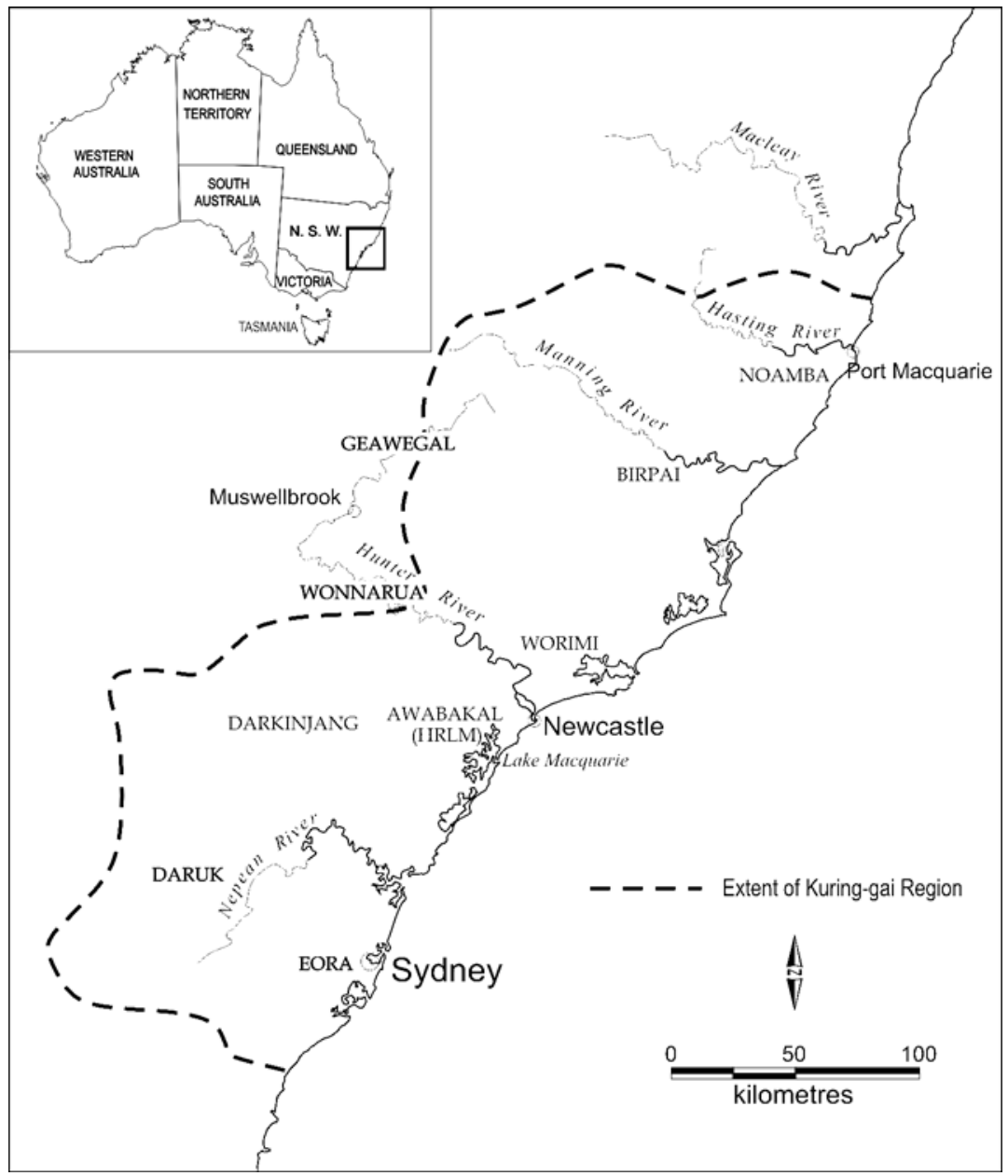

MAP 2 Extent of "Kuring-gai" territory, as imagined by Frazer (1891), with Aboriginal tribal boundaries following Tindale (1974).

When entering the linguistic contact zone, Threlkeld's first task was to create a written form of the language, as had been achieved for New Zealand Maori (Lee and Kendall 1820). His training and qualifications for this task were typically modest. He probably served an apprenticeship as an apothecary as a young man, during which he learned to write the neat copperplate which distinguished his fine copy of the Gospel of St. Luke (1857); his knowledge of grammar was drummed into him by the Rev. Matthew Wilks in the course of basic training as a preacher and missionary in 1815 (Gunson 1974: 17). 
Otherwise, his understanding of the formal structure of languages was picked up by minute interrogation of native informants, first in Raiatea (Society Islands), where he lived from 1817 to 1824, and subsequently among the Aborigines of New South Wales. Threlkeld's Reminiscences, published in serial form in the Presbyterian newspaper the Christian Herald between February 1853 and April 1855 (ibid.: 43-82), provide additional information on his early experiences in acquiring the language. According to this source, published more than twenty years after his time in the field, Threlkeld initially hoped to adopt the method that he had found successful in Raiatea, where he simply allowed his mission subjects free access to his house. However, Threlkeld felt unable to continue this practice in New South Wales because of what he called the "filthy habits and disgusting appearance" of the Aborigines, whose nudity impinged on the modesty of his household (ibid.: 46). Threlkeld remained heavily conflicted in his attitudes to the Aborigines he had chosen to evangelize, denigrating their bodies while seeking simultaneously to elucidate their language and demonstrate their suitability for Christian civilizing efforts. He describes the revulsion he felt when watching Aborigines kill, cook, and eat their prey, consumed with what he derided as the basest of appetites, while the hunter allowed the blood of his kill to stream down his arm (ibid.: 46). Unable to cope with such scenes, he chose instead to give the natives a gun and ammunition, and get them to shoot birds and animals while he followed them about with a notebook in hand, jotting down the words elicited by the hunt in an alphabetical notebook. In this way, Threlkeld hoped to confirm his own status as a gentleman naturalist, who also enlisted trained hunters to kill the specimens they wished to describe, ${ }^{11}$ while separating his endeavors from the primitive chase.

It was at this stage that Biraban seems to have formed a closer association with Threlkeld. In a circular printed report on his efforts from July to October 1828, Threlkeld describes his regular activities to now include conversations with McGill. He found it easiest to direct the conversation toward Aboriginal customs and habits: "Easy sentences, passages from scripture, and information on Christian subjects are attempted" (Gunson 1974: 98). For Biraban's part, it is quite possible that he saw his task as one of educating the missionary about the traditional way of life which was then under radical attack. Such methods returned fruit, and by September 1825 Threlkeld had drafted an "Orthography and Orthoepy of a Dialect of the Aborigines of New South Wales," the manuscript of which can be found among the papers of Sir Thomas Brisbane (Threlkeld 1825), the colonial governor of New South Wales whose support was instrumental in Threlkeld's initial

\footnotetext{
11 With obliging companions, Charles Darwin shot his way to Bathurst on his visit to Australia, expressing his pleasure at being able to observe a freshly shot platypus because it was so much better preserved than stuffed specimens (Darwin 1839, cited by Mackannes 1965: 234).
} 
establishment in the colony. The overall program of passages from scripture, lists of Aboriginal words, and a guide to pronunciation adopted from Walker's Pronouncing Dictionary (1807), is reflected in the material later published in the Australian Spelling Book (1836).

The second stage of Threlkeld's language studies began in 1829 when he moved to a new mission site on land granted to him by Governor Brisbane. For about ten years Ebenezer was, as Gunson (1967) suggests, something of a "showplace" at the boundaries of empire, attracting international visitors such as the Quakers James Backhouse and George Washington Walker, who visited in 1836 (Backhouse 1843: 379-83; 1843), and the linguist and artist of the American Exploring Expedition who came in 1839 (Hale 1846). Over these years, Threlkeld produced a linguistic corpus that included the first draft of the translation of the Gospel of St. Luke, completed in 1829; the unfinished translation of the Gospel of St. Mark (1837); translations of prayers for morning and evening service undertaken at the invitation of the colony's leading Anglican cleric, Archdeacon William Grant Broughton (1788-1853) (Threlkeld 1834b); and his major grammatical study, the Australian Grammar (Threlkeld 1834a). In a note Threlkeld wrote at the beginning of 1834 (cited by Fraser 1892a: xv), he indicated that in this year he was well advanced toward his ultimate goal of translating all four gospels and had begun working on sections of the old testament: he was revising the Gospel of St. Luke for the second time, had the Gospel of St. Mark "in preparation," and had "just commenced" the Gospel of St. Matthew. He was also instructing two native youths, including Biraban's son, in reading and writing their own language, and in conducting reading lessons in passages selected from the Old Testament.

This turned out to be the high point of the colonial linguistic mission, from which it steadily declined. From Threlkeld's recently discovered personal journal (1828), ${ }^{12}$ which includes manuscript versions of the reports he prepared for the LMS and for various colonial authorities (Gunson 1974: 115-23; 13239), we can trace the fortunes of the mission and the disruption of the work of translation created by escalating violence in the colony. In his 1836 Report, he lamented the declining numbers of the Aborigines: "Death in various shapes carried off the tribes, until there is barely the name of a few tribes left in existence in these parts" (Threlkeld 1828-1846: 323). The following year, his report recommended that the work of translation be suspended and that he be allowed to conduct an itinerating mission to parts of the colony where the Aborigines still roamed in significant numbers (Threlkeld 1828-1846: 248). For the time being, he felt obliged to set aside the work of translation: "It would be very gratifying to possess printed copies of the four Gospels and the acts, as

\footnotetext{
12 The journal remains in private hands. Most of its contents, including correspondence, Threlkeld's annual reports, and draft journal entries, were edited by Gunson from archived copies (1974).
} 
originally contemplated," he wrote (ibid.), but he could not justify the expense to the British and Foreign Bible Society. Archdeacon Broughton seems to have felt the same, and in 1831 he asked Threlkeld to suspend work on the translation of the Gospel of St. Luke in order to complete a translation of the Anglican prayers for morning service (Gunson 1974: 115). Threlkeld's 1837 Report recounts, with moralizing disquiet, his distress at the catastrophic loss of life from disease, licentiousness, the depredations of blacks upon each other and especially on black women, and retributions by whites: "He who "increaseth the Nation," or, "destroyeth, that there shall be no inhabitant (Job 12: 23)" has visited the land, and the Measles, the [w] hooping cough, and the influenza, have stretched the Black victims in hundreds on the Earth" (Threlkeld 18281846: 255). At the mission house at Lake Macquarie, which he had been forced to abandon, he reported that sixty blacks lay buried, most of whom had died of prevailing epidemic diseases (ibid.: 248).

The collapse of the language community was also a disaster for the work of translation. While Threlkeld tried everything he could to secure publishers and patrons, thrifty religious publication societies were understandably reluctant to contribute to a project for which there was neither profit nor the prospect of a harvest of souls. Unbeknown to Threlkeld, the deathblow to his publishing ambitions was probably dealt by Archdeacon Broughton. In a letter to the Society for the Promotion of Christian Knowledge (SPCK) in December 1834, Broughton recommended that the Society refrain from attaching its name to a published version of the Gospel of St. Luke. His reasons were that, although the work was proof of Threlkeld's industry and ingenuity, there were, in his opinion, no speakers of the language who "were in a sufficient state of preparation and intelligence to read it if printed and put into their hands" (Gunson 1974: 172). This was above all an insult to Biraban, the authority on whose intelligence and linguistic skill the translation was almost entirely based. Perhaps Biraban felt the slight. In his report to Broughton at the end of 1836, Threlkeld states that while he was sometimes occupied with teaching little Johnny McGill, Biraban's son, and another boy called Billy Blue, Biraban himself was seldom at the mission and had become a drunkard (ibid.: 133). The translation project was shelved and in 1838 Threlkeld become embroiled in the controversy over the Myall Creek murders, supplying evidence of ongoing atrocities committed against Aborigines in the colony which he was powerless to avert (Reynolds 1998; Roberts 2008: 119).

In the next section I consider aspects of Threlkeld's work as a translator conducted while the tides of colonial violence swept around the mission station: I first analyze his relationship with his key informant, Biraban, before turning to a study of the two gospels that provide evidence of their work together. Although Threlkeld actually began work on St. Luke first, it was still in a rough condition when he moved on to St. Mark (Threlkeld 1837). Because it 
remains as more or less a working manuscript, the Gospel of St. Mark actually tells us much more about his methods of translation and will be considered first.

Biraban was clearly central to the translation effort, for, as far as we can tell from Threlkeld's journals, he was Threlkeld's primary informant for his description and translations into HRLM. It is tantalizing to try and reconstruct this pivotal relationship in the way achieved by Brock for new Christian evangelists elsewhere in the British Empire (2005). Her case studies include Tiyo Soga, a Xhosa man who survived the brutal frontier war of southern Africa, Arthur Wellington Clah of British Columbia, Maretu and Ta'unga, Rarotongans for the Cook Islands in the South Pacific, and Moses Tjalkabota who was a western Arrernte from central Australia. But these cases, rare and exceptional as they are, share a number of critical differences from the case under consideration here: all of these men were first-generation Christians, were literate, and wrote their own narratives of Christian conversion. Biraban was illiterate and seems not to have expressed interest in evangelical conversion, and hence our knowledge of him is mediated through the reports of Threlkeld and other Europeans in the colony. Through Threlkeld's "Reminiscences" (Gunson 1974: 47-80), we have a significant body of colonial ethnography which is dependent on Biraban, but which was authored by Threlkeld (1853). There is also a major corpus of translated scripture, which was attributed to Biraban by Threlkeld (1834a; 1837; 1857), but has been rejected by critics such as van Toorn (2006) as not authentically Aboriginal. Seeking to recover Biraban's voice in these contexts presents interpretive challenges that may well be insuperable.

Some suggestions about his working relationship with Threlkeld may nevertheless be gleaned from a series of representative sentences (Threlkeld 1834a), most of which concern the relative power of native chiefs, kings, and the Governor (an English word Threlkeld always left untranslated), and which use the term pirriwul ("chief"). ${ }^{13}$ Aboriginal languages are not rich in terms for members of social hierarchies, and pirriwul is the term regularly deployed by Threlkeld to translate words such as "chief," "king," and "lord" as they arise in scripture. In his Australian Spelling Book (1836: 14), Threlkeld provides thirteen examples of the use of pirriwul in scriptural contexts such as Psalm cxviii.27: "The Lord is God" (Eloi ta Pirriwul ta noa); or more expansively, Jeremiah x.10: "But the LORD is the true God; he is the living God, the eternal King." (Pirriwul ta noa Eloi tuloa kan ta, etc.) The word is also used throughout both the Gospel of St. Mark and the Gospel of St. Luke (1857). A number of sentences in the Australian Grammar (Threlkeld 1834a) suggest this important word may have had a more personal meaning for Biraban, who became "king" or "chief" of the Lake Macquarie Aborigines in

\footnotetext{
13 For additional discussion of the cultural meaning of these representative sentences, see Carey (2009: 167).
} 
about 1833, shortly before the Grammar was published: "I will let you be king (pirriwul)"; "Be king (pirriwul) again"; "Do not let him be king (pirriwul)."

It is more challenging to discern the translation techniques adopted by Biraban and Threlkeld when translating scripture into the HRLM. But a series of eleven illustrative sentences in the same Grammar (ibid.: 128), suggest the following scenario: Threlkeld at his desk; his asking Biraban to speak slowly and distinctly; a plea to stay and continue the work; and a clock marking out the hour of the engagement. The English translations of these sentences read:

Speak to me in the black's language.

Tell me again. Speak distinctly.

What shall we two first talk about?

Stay, stay, that I may have some conversation.

What is the name of this? How am I to call, etc.?

What did he tell you?

I command thee to arise.

This is where we formerly conversed together.

The clock has done striking.

Such sentences suggest at a relationship that was conducted to a standard missionary schedule (Comaroff 1991): the clock ticked, and Biraban may have sometimes become restless, but Threlkeld insisted that he remain at his post. To find out more, we must turn to the texts of the translated gospels and especially to the manuscript evidence of the Gospel of St. Mark.

\section{COLONIAL GOSPEL: ST. MARK ( 1837$)$}

Threlkeld's Gospel of St. Mark was a substantial undertaking. Although St. Mark is the shortest of the four gospels, Threlkeld's manuscript version still amounts to 283 folios and, like all attempts at scripture translation, demanded the most strenuous intellectual, linguistic, and philosophical efforts. The date atop the first page is Tuesday, 13 December 1836; the final date, at the end of the sixteenth chapter, is 23 June 1837. The translation was therefore begun about five years after completing the first draft of the Gospel of St. Luke in 1831. But although the team therefore worked on this project for at least six months, there are many signs that Threlkeld never considered it complete.

The most obvious indication is the extensive corrections and marginal annotations throughout the manuscript (see Figure 1). Threlkeld appears to have adopted a system where he underscored words where he felt some doubt about the sense, or where there were possible alternative translations. Comments were placed in the margins, while in the text Threlkeld put alternate readings within angle brackets or occasionally in bold. There are corrections that he marked by cross-scoring individual words and inserting something new above the line; where inspiration failed altogether he simply left a blank. The number 


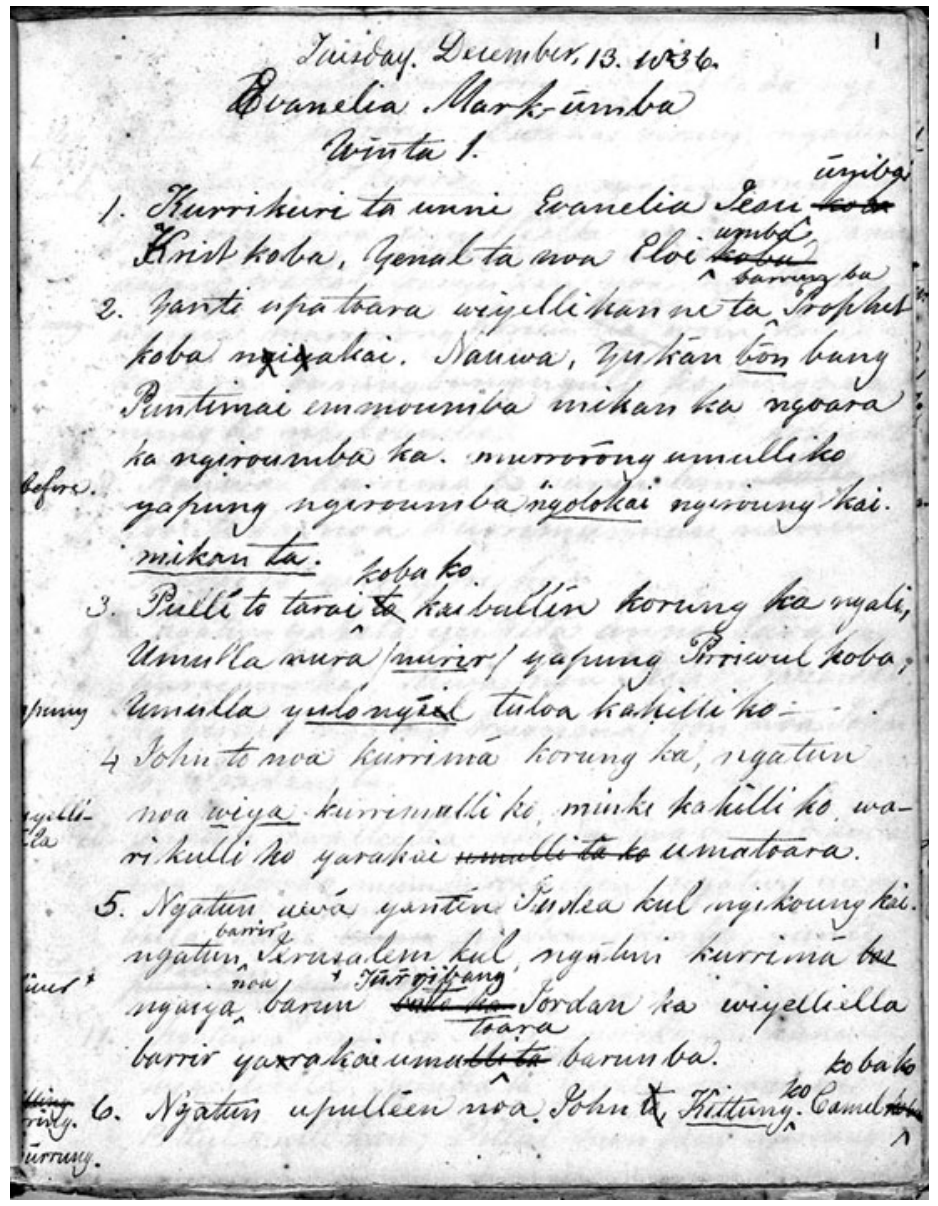

Figure 1 Opening chapter of the HRLM Gospel of St Mark (1837). With permission of Mitchell Library, State Library of New South Wales, ML MSS 2111/2.

of marginal notes varies from chapter to chapter: chapter 15 has as many as twenty-two, whereas there are only seven for chapter 16. A great many of these marginal queries are left unanswered and we are left to speculate whether Threlkeld was unable to secure an appointment with Biraban or another native speaker to clear them up. Some of these unanswered queries relate to problematic words or concepts, others concern grammatical points. In the first chapter Threlkeld chose to leaves a good many words untranslated, or slightly modified to make them easier to pronounce, including evanelia ("gospel"), Eloi (God), and sunagog (synagogue). Threlkeld devoted some pains to his choice of the right word for "God." He adopted Eloi for the 
translations of the Gospel of St. Mark and the Anglican morning service; but the earliest version of his grammar (Threlkeld 1834a) makes use of "Jehovah," another Hebrew term adapted into English, and it is Jehovah who is described in Biraban's dream vision as a shining, flying figure, "He about whom the whites speak," in Threlkeld's 1836 Report to Broughton (Gunson 1974: 134). In the Gospel of St. Luke, his earlier draft used Jehovah, but the 1858 version is amended to Eloi, possibly simply because it was shorter (see Appendix).

Elsewhere, Threlkeld scores out word endings, replacing Evanelia Iesu-ko-ba ("the Gospel of Jesus) with Evanelia Iesu-ūmba ("the Gospel according to Jesus"). There are marginal notes seeking the words for "before" (ngolokai), "river" (tūrribang), "girdle" (purrān), or bird (tibbin), where he seems to have returned to correct earlier omissions. Sometimes there are alternatives, as at the head of verse 23 (King James Version: "And there was in their synagogue a man with an unclean spirit"), where he asks: "Scribe kiloa or Scribe ba kiloa?" Underscoring seems to indicate that Biraban suggested he choose the latter. One indication of the challenge facing Threlkeld (and many other missionary translators) in trying to create appropriate language for the complex narrative and intellectual issues encountered in scripture is the number of English words which appear, more or less undigested, in the texts. These appear on every page and include words for most numbers, exotic foods, and agricultural and military activities unknown in Aboriginal life: they include harvest (4.29), mustard (4.31), and devil $(5.12,16.9)$. Soldier, pretorium, temple, and centurion appear in the one challenging verse (15.16), with crown and purple popping up in the next (15.17). In the course of the translation, every line presented new interpretive conundrums whether of word choice, syntax, interpretation, or emphasis. The evidence of the manuscript of the Gospel of St. Mark suggests that for the final choice of words Threlkeld deferred to Biraban.

The translation of Christian religious concepts into a new language was generally recognized by missionary authorities as fraught with the danger of contaminating the sacred text with pagan ideas. Nevertheless, as generations of earlier scripture translators had demonstrated, such issues were not necessarily insurmountable barriers to effective translations. The representative sentences in the Spelling Book (1836: 13-15) show that by 1836 Threlkeld had already decided on a series of words, some in HRLM such as pirriwul ("Lord"), marai ("soul"), yirriyirri ("holy"), and others borrowed from English or Hebrew such as Eloi ("God") and Messiah, to represent key concepts required for scripture translations. Threlkeld managed to complete an interlineated translation of the Lord's Prayer (Threlkeld 1850: 68; Lissarrague 2006: 271-72), which demonstrates that he eventually established suitable translations for other key terms such as "heaven" (muruku), "earth" (parray), "evil" (yarakay), and "glory," for which he adopted the Hunter River word 
for "shine" (kilipiynpiyn). In addition, Threlkeld and Biraban had complied with Archdeacon Broughton's request that they prepare translations of the Anglican Morning Service (Threlkeld 1834b; edited by Fraser 1892: Part IV.E). Broughton is not known to have used these translations for services, and as a Congregationalist Threlkeld had no cause or authority to do so, however they demonstrate that HRLM was rich enough to serve the Anglican liturgy, and as the translation of scripture. Nevertheless, for a range of other, practical reasons, the challenges of completing their translation of the Gospel of St. Mark did defeat them.

\section{COLONIAL GOSPEL: ST. LUKE}

In contrast with the Gospel of St. Mark, the Gospel of St. Luke, or "Evangelion Unni ta Jesu-ūm-ba Christ-ko-ba Upatōara Louka-ūmba," to give it the title of the unique manuscript now in the Auckland Public Library, was the result of careful revision completed over twenty-eight years. The first draft of the St. Luke translation was made in 1829 and a third revision was completed in 1831, each of which was checked by Biraban. In the preface Threlkeld explains his method of working: "Thrice I wrote it, and he and I went through it sentence by sentence, and word for word, explaining to him most carefully the meaning as we proceeded. McGill spoke the English Language fluently" (1857: fol. Vii). Important evidence of the kinds of changes that the revision of the text of the Gospel of St. Luke went through is found in Threlkeld's circular report on the mission distributed on 8 October 1828. This report includes two versions of Luke 7:11 to 7:16, demonstrating the revisions made between 1828 and 1838 (Gunson 1974: 100-1; and see Appendix, below). Changes were made at every level of the text, including orthography, word order, vocabulary, and syntax. If this is a fair example of the extent of the revisions Threlkeld completed throughout the whole manuscript, it is not surprising that it took him so long to complete his work.

As we might expect, the Gospel of St. Luke shows a more assured use of the language with less resort to English than does the un-revised Gospel of St. Mark. Threlkeld is careful to avoid translating Christian spirit beings with native terms, whether hostile, such as Puttikán ("biter"), or Koyorowen or Kurriwilbam, or beneficent, such as the "unknown being," possibly a sky god, Koun, whose other names were Tippakal and Por-rang (ibid.: 61-62). The word puntimai ("messenger"), however, is an exception to this strict policy of spiritual quarantine. The puntimai was responsible for summoning tribes to witness punishment; they also brought what Threlkeld reported to be popular songs, some of which had a prophetic character (ibid.: 58, 191). Carrying verses and songs between tribes, they initiated the traveling cults such as the smallpox waganna reported by missionaries stationed over the mountains in Wellington Valley in the 1830s (Carey and Roberts 2002). Threlkeld seems to have been aware of this, and rather delighted by the parallel it presented 
to Christian religious enthusiasm and prophecy. In the Gospel of St. Luke, he adopts the term to refer to the Angel Gabriel on his visit to the Virgin Mary (Luke 1:27) and also for John the Baptist (Luke 7: 27). In another innovation, he uses a term for sacred business, yiriyiri, to translate "Holy Spirit" (Luke 1:15, 1:67), "holy prophet" (Luke 1:70: propet koba ko yirriyirrikan), and "holiness and righteousness" (Luke 1:75: yirriyirrikan atun murrārāngkan). Weaving words with traditional religious meanings into scripture has its hazards, ${ }^{14}$ but it was also the way in which Christianity was acclimatized within a new cultural regime. In the Gospel of St. Luke, this process appears well developed. It proceeded no further, of course, because the mission failed and all its speakers died. It became a book that no one could read.

With the closure of the Ebenezer mission in 1841, and the death of Biraban in 1846 , one might have expected the translation project to come to an end. Surprisingly, it was to undergo a revival in a number of new colonial modes, most notably that of display. The fate of the Gospel of St. Luke was redeemed from the other side of the globe at the intervention of Sir George Grey (1812-1898), linguist, explorer, collector, and, at the time he wrote to Threlkeld, British governor of the Cape Colony. Twenty years after Threlkeld had last set St. Luke aside, no doubt all too aware of its deficiencies, Threlkeld received a letter from Grey that galvanized him, in the final years of his life, to complete a fourth and final revision. Threlkeld had first written to Grey in January 1850, when he sent him a copy of the Key to the Structure of the Aboriginal Language (Threlkeld 1850; Gunson 1974, 295). In his reply, dated 19 May 1851, Grey asked him to send him a copy of any of his scripture translations, but Threlkeld expressed the view that his existing manuscript translations, which probably included Luke, Mark, and possibly Matthew, "would not be of service" (Gunson 1974: 297). In February 1857 Grey tried again, this time offering to pay to have copies made by his agents in Sydney (ibid.: 300). Threlkeld refused to accept any payment, but he replied on 10 April to say that he would copy the Gospel of St. Luke himself so as to avoid errors of transcription (ibid.: 300). Grey, delighted, stooped to flattery, and in a letter from Cape Town of 10 July 1857 he called Threlkeld "the Father of discovery in reference to the Language in Australia" (ibid.: 301). Grey's keen engagement at this time may spring in part from the impetus provided by the Prussian philologist Wilhelm Bleek (1827-1875). Bleek's superb three-volume catalogue of the Grey's African, Australian, and Polynesian philological collections appeared between 1858 and 1863 (Bleek and Cameron 1858), and it is possible that

\footnotetext{
${ }^{14}$ Notable here is the colonialist concept of the "dreamtime," which Wolfe (1991) argues originated with the decision by German Lutheran missionaries in Central Australia to use the Arunta word altjira ("from the beginning") to stand for the German Gott in scripture translations and hymns.
} 
he busied himself not just with cataloguing the existing grammars but also inspiring Grey to commission new ones from missionaries still in the field.

Threlkeld was finally able to forward to Grey the completed copy of his Gospel of St. Luke in July 1858. By this time Biraban had been dead for twelve years and Threlkeld himself stated that all speakers of the language that was the subject of his labors were fast becoming extinct (1857: fol. Iii). Nevertheless, he compared his own situation with that of John Elliot, "the Missionary to the North American Indians," and, incidentally, one of the figures in the window of Bible House mentioned at the beginning of this essay. According to Threlkeld, Elliot's translations had "recently been published," even though only one speaker of the Algonquin language of Massachusetts remained (ibid.: fol. Vii). ${ }^{15}$ Clearly there was still hope for the Australian gospel. Nevertheless, time really had run out at last. Comparing the version of Luke 7:11 copied for Grey in 1857 with the version Threlkeld had revised in 1838 in consultation with Biraban, it is evident that he made few if any changes in this final version (see Appendix 1). Perhaps for this reason, Threlkeld seemed aware that many deficiencies remained, but also that it represented the best he was capable of: "This present copy of the Gospel by Luke is the fourth rewritten revisal of the work, and, yet, it is not offered as a perfect translation, it can only be regarded by posterity as a specimen of the language of the Aborigines of New Holland, or, as a simple monumental Tablet, on which might be truthfully inscribed, as regards the unprofitable servant who attempted to ameliorate the pitiable condition of the Aborigines and attain a knowledge of their language:-_He has done what he could"' (Threlkeld 1857: fol. Viii).

Threlkeld had hoped to be able to complete a Lexicon that would provide a gloss for every word in his translation of St. Luke, but at the time of his death this had been completed only up to the letter K. In its incomplete state, the Lexicon was finally forwarded to Grey by Threlkeld's son, who on 17 December 1859 wrote that he hoped it would be of some use as his father's final memorial (Fraser 1892: Part III).

\section{MEMORIALIZATION AND RE-COLONIZATION}

The memorialization of Threlkeld's linguistic writings had in fact already begun to occur well before his son made this suggestion to Sir George Grey in a conventional gesture of filial piety. Indeed, it began less than a decade after the closure of Threlkeld's Ebenezer mission in 1841. While despairing at the collapse in the mission's population, Threlkeld was ingenious in recognizing that his linguistic studies might still serve a useful purpose. In effect, he

\footnotetext{
15 The first edition of Elliot's translation into "the Indian Language" appeared in 1663, and a second, corrected edition was published in 1685. It was not reprinted in the nineteenth century and it is not clear where Threlkeld's information comes from. Threlkeld is likely to have identified with Elliot, a fellow Independent.
} 
willingly let his missionary linguistics to be colonized by allowing them to be made available to colonial authorities to be used as exhibition items.

The first work to be re-colonized in this way was Threlkeld's major grammatical study, the 1834 Australian Grammar, but the movement was eventually to incorporate almost everything he had written on the language. While Threlkeld's Grammar could no longer serve in the evangelization of the Hunter River and Lake Macquarie people - a people who no longer existed as a language community - its publication had been subsidized from the public purse and it might very effectively represent the native people of Australia to the imperial public. In 1850, Threlkeld therefore prepared a new version, calling it $A$ Key to the Structure of the Aboriginal Language. This was published in Sydney by Kemp and Fairfax for inclusion in the New South Wales colonial display at the Royal Exhibition which was held in London's Crystal Palace in 1851. Threlkeld used this new publication to create a memorial to his old informant, Biraban, writing the generous tribute and including the portrait referred to earlier.

The second work to be revived was the Gospel of St. Luke. In 1857, as we have seen, Threlkeld was inspired to create a fourth revision of this at Grey's invitation. For Grey Threlkeld had prepared a careful calligraphic copy of the work he called a "simple monumental Tablet"; this was to take its place in the collection which Grey was then assembling of rare and precious manuscripts and printed books. As Kerr (2006: 126-33) demonstrates, Grey's contact with Threlkeld was part of a systematic program of acquisition of African, Malagasy, Pacific Islander, and Australian Aboriginal linguistic items, and included approaches to other missionaries including C. W. Schürmann and C. G. Teichelmann in South Australia.

The Gospel of St. Luke was firmly located in the scientific and ethnographic part of Grey's collection. But Grey seems to have wanted to do something special for the work that Wilhelm Bleek considered to be the most significant achievement in Australian linguistics as well as the first attempt at an Australian Bible. At some point after 1857, when he received Threlkeld's manuscript, Grey decided to commission the artist Anne Layard, wife of the British naturalist Edgar Leopold Layard (1824-1900), to provide a decorative scheme for his new acquisition, in the fashionable "Gothic" or medieval style that was becoming increasingly popular in the colonies (Andrews 2001; Kerr and Broadbent 1980; Trigg 2005). Layard's scheme of decoration incorporated portraits of both Biraban and Threlkeld, but also a decorated initial in the style of the Book of Lindisfarne, and a new miniature of St. Luke the Evangelist, possibly copied from a late-fourteenth or early-fifteenth-century French gospel book or book of hours, which Grey collected for the libraries he founded in the Cape and in New Zealand (Kerr 2006). Layard's image of the evangelist is surrounded by a border of Australian birds that may have been sourced with the assistance of Anne's ornithologist husband. This medieval makeover 
represents the final transformation of the work of the missionary scholar and his Aboriginal collaborator: it removed them decisively from the violent reality of the mission and the contact zone in which they had worked together. It is unlikely that Threlkeld would have agreed to the decoration of his work in this way, which was at best unsympathetic to the taste and religious sensibilities of the Congregationalist minister (who was deeply anti-Catholic), and at worst a final act of colonial appropriation.

With Threlkeld's death, it might be thought that his work was at an end and that he had finally "done what he could," and that his remaining unpublished linguistic writings, including the now finely decorated Gospel of St. Luke and the forgotten Gospel of St. Mark, would never find a publisher. However, the memorializing potential of his writings continued to attract a new audience for another, even greater exhibition at the end of the century. In the 1890s, the linguist and schoolmaster John Fraser was commissioned by the New South Wales government to prepare a comprehensive collection of Aboriginal linguistic material for inclusion in the Columbian "World's Exhibition," or the Chicago World Fair, which was held in 1893 to commemorate the five hundredth anniversary of Columbus's voyage to the New World. It included most of Threlkeld's printed grammars as well as the unprinted Gospel of St. Luke from the Grey Collection in Auckland. For the New South Wales exhibit (Bertuca, Hartman, and Neumeister 1996: 243), Fraser created a handsome volume in which Threlkeld's translations and grammars were the most significant items. Other than word lists and sentences, it was the only printed edition of any substantive work in any Australian Aboriginal language published for generations to come.

POST-COLONIAL AFTERMATH

After the colonial era, English-speaking missionaries in Australia put a particularly low priority on teaching and learning Aboriginal languages: the legacy of Threlkeld and other missionary linguists was largely forgotten. A small number of missionaries chose to struggle, unsupported, to learn Aboriginal languages, but it was more usual to assume that their Aboriginal students would learn English and forget their own languages. Harris quotes one missionary to this effect: "You had to communicate somehow," he recalls, "but you always hoped for the day when their English would be good enough" (1995: 238). Writing of his parents Len and Nell Harris, who read Anglican services in the Gunwinggu language at the Anglican Church Missionary Society mission of Oenpelli, Northern Territory in the 1930s, Harris denotes their efforts as "one of the most important events in Australian Christian history" because it was the first time since European colonization that the Bible was read in an Aboriginal language in an Anglican church (2002: 238). But, as Capell (1970: 23) was aware, scripture translation in Australia began more than a hundred years earlier, with Threlkeld. Others showed less awareness 
of their precursors. Studies by Harris $(1987 ; 1994 ; 1995)$ and Oates $(1999)$ of the projects of the Summer Institute of Linguistics stress the paucity of translations and linguistic work prior to the inauguration of its Australian Aborigines Branch in 1961. Harris suggests that not until the work of Carl Strehlow at Hermannsburg was any significant scripture translation done in any Aboriginal language, and he sees Strehlow's translation of the gospels into Aranda (Strehlow 1925), rather than Threlkeld and Biraban's work in the previous century, as the real watershed event in the history of the Aboriginal Bible. Since the 1960s, the Summer Institute of Linguistics has continued to play an important role in reinvigorating missionary linguistics in Australia, and in providing support for field workers interested in continuing older Protestant traditions of scripture translation and the composition of other religious works in Aboriginal vernaculars (Poole 1988).

New post-colonial forms of the Threlkeld and Biraban scripture translations continue to be generated, despite the absence of speakers of HRLM, or cognate languages throughout coastal regions of New South Wales. In the Hunter Valley where the text was originally created, a scan of Fraser's 1892 edition formed the basis for the new edition of the "Awabakal" Gospel of St. Luke published by the Bible Society (Threlkeld 1997). This 1997 edition has been incorporated into the new discourse of "Aboriginal reconciliation" negotiated by modern churches with representatives of contemporary Aboriginal communities. It bears a statement, signed by church leaders from across Newcastle: "This ... Gospel of Luke was presented to the indigenous communities of the greater Newcastle area on Sunday, 14 December 1997 at Cullen Park, Belmont, as a symbol of our desire to be reconciled and to walk together now and in the future" (Threlkeld 1997: 3).

\section{CONCLUSION}

Over the course of his life, Threlkeld never entirely abandoned his hope of completing a full translation of all four gospels and the Acts of the Apostles. But even after years of exertion, the text I have been calling "the colonial Bible" never amounted to more than two gospels from the New Testament and a few passages from the old. Even these fragments were not published in the lifetimes of either the missionary or his collaborator Biraban. Indeed, with the extinction of the translation's language, the whole project can be depicted as irretrievably mired in conflict and tragedy.

I have argued in this article for the significance of the colonial setting in which the translations were created. That they exist at all is the result of the partnership of two people: Threlkeld, the missionary, and his informant and inspiration, Biraban, "chief" of the Hunter River and Lake Macquarie people. Threlkeld brought with him the cultural assumptions and inheritance of a Christian missionary who wished to carry forward the "Great Commission": this provided the motivating force that propelled the project. Threlkeld 
no doubt aspired to be remembered as the first apostle of the Australians, in the same pantheon as Elliot in America, Carey in India, Morrison in China, or Moffat in Africa, though if he wished for a rapid path to popular esteem he choose a laborious and unrewarding route. As an agent of the London Missionary Society, he took comfort in the religious aspects of his obligations: the modest rewards for his missionary labors might be depicted, using the language of scripture, as part of the "day of small things." Threlkeld also saw himself as an heir of the enlightenment intent on bringing scientific rigor to the execution of a missionary responsibility. Therefore, when the LMS withdrew its support he was able to reinvent himself as a linguistic authority, a translator, and protector of Aborigines. It was just as well that Threlkeld was steeled intellectually and religiously for the task he took on, because they were carried forward under the most adverse circumstances. While the number of Aboriginal deaths remains contested, Threlkeld certainly buried many people to whom he had once hoped to preach in their own language, and the loss of the language community cannot be disputed.

It is more difficult to enter either sympathetically and critically into the motivation of Threlkeld's collaborator, Biraban. We have no direct evidence of what he thought about the decline of his people or the creation of a Christian literature in his mother tongue. While he persisted in working with Threlkeld as a translator, accepting the appointments under the mission clock, it is likely that he regarded this linguistic service as the equivalent of the other jobs he performed for Europeans entering what they imagined to be a colonial wilderness. The language of scripture often proved elusive, but perhaps no more so than were the escaped convicts Biraban was engaged to hunt and retrieve, or the visiting clergy, scholars, and explorers he guided through the bush to the mission at Lake Macquarie. Nevertheless, while both the Gospel of St. Mark and the Gospel of St. Luke must properly be represented as colonizing texts, whose hesitations and word choice reflect the hegemonic imposition of the European colonial order over Aborigines throughout New South Wales, they are also evidence of a rare and productive working relationship.

Further testimony to the effectiveness and symbolic power of the translations and grammatical studies that Threlkeld and Biraban created is their remarkable adaptability, evidenced by their redeployment in a variety of guises in the decades that followed the end of the colonial mission. I have argued that the texts can be seen to reflect the historical changes in the environment in which they were created: from the arrival of the missionary in the contact zone to the republication of the "Awabakal" gospel by supporters of the contemporary movement for Aboriginal reconciliation, the creation and reception of the translations shift from evangelical, to colonial, to post-colonial, and ultimately de-colonizing modes. There is tragic irony in the fact that the New South Wales government should have chosen to display, as characteristic exhibits of the colony, linguistic artefacts of the people who had been driven from 
their homelands as a consequence of British colonization. This irony may have been lost even on Threlkeld, who saw the 1851 Exhibition as, at least in part, an opportunity to pay tribute to his old collaborator and to gain some recognition for their years of labor. Threlkeld's and Biraban's translations have been used to represent an extinct Aboriginal language and people to both imperial and a post-colonial worlds.

\section{APPENDIX 1}

Comparison of Threlkeld and Biraban's 1828, 1838 and 1857 revisions of Luke 7:11 and the King James Version. Source: Threlkeld Journal, 8 October 1828 [Gunson 1974: 101]; Threlkeld Gospel of St. Luke [1857].

1. Luke 7:11 (King James Version): And it came to pass the day after, that he went into a city called Nain; and many of his disciples went with him, and much people.

2. Luke 7:11 (1828)

$\begin{array}{llllll}\text { Tahri } & \text { ta } & \text { untah } & \text { Purreung-ka } & \text { uwah } & \text { noah } \\ \text { another } & \text { it } & \text { was it } & \text { Day } & \text { came } & \text { he } \\ \text { Jesu } & \text { Nain } & \text { kolang, } & \text { kowwl } & \text { ngekoung } & \text { katoah } \\ \text { Jesus } & \text { Nain } & \text { towards, great } & \text { his } & \text { with } \\ \text { uwah, } & \text { kowwol } & \text { ngiya } & \text { kora } & & \\ \text { came, } & \text { great or many } & \text { then } & \text { men } & & \end{array}$

3. Luke 7:11 (1838)

$\begin{array}{lllll}\text { Ngatun } & \text { yakita } & \text { purreung-ka } & \text { yukita, } & \text { uwa } \\ \text { And } & \text { at that time } & \text { day was } & \text { afterwards, } & \text { came } \\ \text { noa } & \text { kokeroa, } & \text { ngiakai } & \text { yitara } & \text { Nain: } \\ \text { he } & \text { into the house place, } & \text { thus } & \text { name it } & \text { Nain; } \\ \text { ngatun } & \text { kauwul } & \text { uwa } & \text { ngikoumba } & \text { wirrobulli-kan } \\ \text { and } & \text { great } & \text { came } & \text { his } & \text { followers, } \\ \text { ngatun } & \text { turai } & \text { kan } & \text { kore } & \text { ngikoung-katoa } \\ \text { and } & \text { other } & \text { beings } & \text { men } & \text { Him with }\end{array}$

4. Luke 7:11 (1857)

$\begin{array}{lllll}\text { Ngatun } & \text { yakita } & \text { purreung ka } & \text { yukita, } & \text { uwa } \\ \text { And } & \text { at that time } & \text { day was } & \text { afterwards, } & \text { came } \\ \text { noa } & \text { kokeroa, } & \text { ngiakai } & \text { yitarra } & \text { Nain: } \\ \text { he } & \text { into the house place, } & \text { thus } & \text { name it } & \text { Nain; } \\ \text { ngatun } & \text { kauwul } & \text { uwa } & \text { ngikoumba } & \text { wirrobulli-kan } \\ \text { and } & \text { great } & \text { came } & \text { his } & \text { followers, } \\ \text { ngatun } & \text { turaikan } & & \text { kore } & \text { ngikoung-katoa } \\ \text { and } & \text { other beings } & & \text { men } & \text { Him with }\end{array}$

REFERENCES

Andrews, Brian. 2001. Australian Gothic: The Gothic Revival in Australian Architecture. Melbourne: Melbourne University Press.

Backhouse, James. 1843. A Narrative of a Visit to the Australian Colonies. London: Davey and Darton. 
Batalden, Stephen K., Kathleen Cann, and, John Dean. 2004. Sowing the Word: The Cultural Impact of the British and Foreign Bible Society, 1804-2004. Bible in the Modern World 3. Sheffield: Sheffield Phoenix.

Bertuca, David J., Donald K. Hartman, and, Susan M. Neumeister. 1996. The World's Columbian Exposition: A Centennial Bibliographic Guide. Bibliographies and Indexes in American History, no. 26. Westport, Conn. and London: Greenwood Press.

Bleek, W.H.I. and James Cameron. 1858. The Library of His Excellency Sir George Grey. K.C.B. Philology. 3 vols. London: Trübner.

Bliss, Edwin Munsell, ed. 1891. The Encyclopaedia of Missions. New York: Funk and Wagnells.

Brock, Peggy. 2005. Setting the Record Straight: New Christians and Mission Christianity. In P. Brock, ed., Indigenous Peoples and Religious Change. Leiden: Brill, 107-28.

Brook, J. and J. L. Kohen. 1991. The Parramatta Native Institution and the Black Town: A History. Sydney: University of New South Wales Press.

Canton, William. 1904. A History of the British and Foreign Bible Society. 5 vols. London: John Murray.

Capell, Arthur. 1970. Aboriginal Languages in the South Central Coast, New South Wales. Oceania 41, 1: 20-27.

Carey, Hilary M. 1998. "The Land of Byamee": K. Langloh Parker, David Unaipon, and Popular Aboriginality in the Assimilation Era. Journal of Religious History 22, 2: $200-18$.

Carey, Hilary M. 2004. Lancelot Threlkeld and Missionary Linguistics in Australia to 1850. In Otto Zwartjes and, Even Hovdhaugen, eds., Missionary Linguistics. Amsterdam: John Benjamins, 253-75.

Carey, Hilary M. 2009. Death, God and Linguistics: Conversations with Missionaries on the Australian Frontier, 1824-1845. Australian Historical Studies 40, 2: 167-77.

Carey, Hilary M. and David Roberts. 2002. Smallpox and the Baiame Waganna of Wellington Valley, New South Wales, 1829-1840. The Earliest Nativist Movement in Aboriginal Australia. Ethnohistory 49, 4: 821-69.

Carey, William. 2004 [1792]. An Enquiry into the Obligations of Christians to Use Means for the Conversion of the Heathen. N.p.: Kessinger Publishing.

Champion, B. W. 1939. Lancelot Edward Threlkeld. His Life and Work, 1788-1859. Journal and Proceedings of the Royal Australian Historical Society 25: 341-411.

Churches, J. 2002. Finding Aid. Evangelical Lutheran Immanuel Synod of Australia Records, MS 3761. Australian Institute of Aboriginal and Torres Strait Islander Studies, Canberra. At: http://www1.aiatsis.gov.au/finding_aids/MS3761.htm.

Cleary, Tania. 1993. Poignant Regalia: $19^{\text {th }}$-Century Aboriginal Breastplates \& Images. Sydney: Historic Houses Trust of New South Wales.

Comaroff, Jean. 1991. Missionaries and Mechanical Clocks: An Essay on Religion and History in South Africa. Journal of Religion 71, 1: 1-17.

Comaroff, John and Jean Comaroff. 1997. Of Revelation and Revolution, Vol. 2: The Dialectics of Modernity on a South African Frontier. Chicago: University of Chicago Press.

Cox, Jeffrey. 2008. The British Missionary Enterprise Since 1700. Christianity and Society in the Modern World. London: Routledge.

Dance, D. G., ed. 1963. Oceanic Scriptures. A Revision of the Oceanic Sections of the Darlow and Moule Historical Catalogue of Printed Bibles, with Additions to 1962. London: British and Foreign Bible Society.

Dixon, Robert M. W. 2002. Australian Languages: Their Nature and Development. Cambridge Language Surveys. Cambridge: Cambridge University Press.

Elliot, John. 1663. The Holy Bible Containing the Old Testament and the New Translated in the Indian Language. Cambridge: Green and Johnson. 
Errington, Joseph. 2001. Colonial Linguistics. Annual Review of Anthropology 30: 19-39.

Fabian, Johannes. 1983. Missions and the Colonization of African Languages: Developments in the Former Belgian Congo. Canadian Journal of African Studies 17, 2: 165-87.

Fabian, Johannes. 1986. Language and Colonial Power: The Appropriation of Swahili in the Former Belgian Congo, 1880-1938. Cambridge: Cambridge University Press.

Fabian, Johannes. 1990. Religious and Secular Colonization: Common Ground. History and Anthropology 4, 2: 339-55.

Ferguson, Charles A. 1987. Literacy in a Hunting-Gathering Society: The Case of the Diyari. Journal of Anthropological Research 43, 3: 223-37.

Fraser, John, ed. 1891. The Gospel of St. Luke Translated in the Language of the Awabakal by L. E. Threlkeld. Sydney: Government Printer.

Fraser, John, ed. 1892. An Australian Language as Spoken by the Awabakal the People of Awaba or Lake Macquarie (Near Newcastle, New South Wales) Being an Account of Their Language, Traditions, and Customs, by L. E. Threlkeld. Sydney: Government Printer.

Fraser, John. 1892a. Fraser to secretary, British and Foreign Bible Society, 28 May. Bible Society Collection, Cambridge University Library.

Gardner, Helen Bethea. 2006a. Gathering for God: George Brown in Oceania. Dunedin: Otago University Press.

Gardner, Helen Bethea. 2006b. "New Heaven and New Earth": Translation and Conversion on Aneityu. Journal of Pacific History 41, 3: 293-311.

Gilmour, Rachael. 2004. Colonization and Linguistic Representation: British Methodist Grammarians' Approaches to Xhosa, 1834-1850. In Otto Zwartjes and, Even Hovdhaugen, eds., Missionary Linguistics/Lingüistica Misionera: Selected Papers from the First International Conference in Missionary Linguistics, Oslo, 13-16 March 2003. Amsterdam and Philadelphia: John Benjamins, 113-40.

Gilmour, Rachael. 2006. Grammars of Colonialism: Representing Languages in Colonial South Africa. Basingstoke: Palgrave.

Gilmour, Rachael. 2007. Missionaries, Colonialism and Language in NineteenthCentury South Africa. History Compass 5: 1761-77.

González-Llubera, Ignacio, ed. 1926. Antonia De Nebrija, Gramática de la Lengua Castellana. London: Oxford University Press.

Grey, Sir George, 1851-1859. Correspondence, GL-1329-1330, Auckland Public Library, Auckland; State Library of New South Wales, Sydney. Repr. in Niel Gunson, ed., Australian Reminiscences and Papers of L. E. Threlkeld. 2 vols. Canberra: Australian Institute of Aboriginal Studies, 1974, 300-88, passim]

Gunson, W. Niel. 1966. Biraban (fl. 1819-1842). Australian Dictionary of Biography. Vol. 2. Melbourne: Melbourne University Press, 102-4.

Gunson, W. Niel. 1967. Threlkeld, Lancelot Edward (1788-1859). Australian Dictionary of Biography. Vol. 2. Melbourne: Melbourne University Press, 528-30.

Gunson, W. Niel, ed. 1974. Australian Reminiscences and Papers of L. E. Threlkeld. 2 vols. Ethnohistory Series 2. Canberra: Australian Institute of Aboriginal Studies.

Hale, Horatio. 1846. The Languages of Australia. In Ethnography and Philology. Reports of the United States Exploring Expedition, vol. 6. Philadelphia: Lea and Blanchard, 457-531.

Harris, John W. 1987. Aboriginal Languages in Church and School: An Analysis of the Northern Territory Experience: Part 1: From the First Missions to the 1940s. Journal of Christian Education Paper 90: 19-33.

Harris, John W. 1994. Aboriginal Languages in Church and School: An Analysis of the Northern Territory Experience, Part 2: From the 1940s to 1973. Journal of Christian Education Paper 37, 2: 39-51. 
Harris, John W. 1995. Aboriginal Languages, Christian Missionaries, and Bible Translation. Studies in the Humanities 22, 1 and 2: 127-43.

Harris, John W. 2002. Anglicanism and Indigenous Peoples. In Bruce Kaye, ed., Anglicanism in Australia. Melbourne: Melbourne University Press, 223-46.

Hiatt, L. R. 1996. Arguments about Aborigines: Australia and the Evolution of Social Anthropology. Cambridge: Cambridge University Press.

Hovdhaugen, Even, ed. 1996. ... and the Word Was God: Missionary Linguistics and Missionary Grammar. Münster: Nodus Publikationen.

Johnston, Anna. 2001. The Book Eaters: Textuality. Modernity and the London Missionary Society. Semeia: $1-15$.

Johnston, Anna. 2003. Missionary Writing and Empire, 1800-1860. Cambridge Studies in Nineteenth-Century Literature and Culture 8. Cambridge: Cambridge University Press.

Johnston, Anna. 2006. A Blister on the Imperial Antipodes: Lancelot Edward Threlkeld in Polynesia and Australia. In David Lambert and, Alan Lester, eds., Imperial Careering in the Long Nineteenth Century. Cambridge: Cambridge University Press, 58-87.

Kerr, Donald Jackson. 2006. Amassing Treasures for All Times: Sir George Grey, Colonial Bookman and Collector. Dunedin: Otago University Press.

Kerr, Joan, and James Broadbent. 1980. Gothick Taste in the Colony of New South Wales. Sydney: David Ells Press, in association with the Elizabeth Bay House Trust.

Koerner, E.F.K. 2004. Notes on Missionary Linguistics in North America. In Otto Zwartjes and Even Hovdhaugen, eds., Missionary Linguistics. Amsterdam: John Benjamins, 47-80.

Larson, Pier M. 2009. Ocean of Letters: Language and Creolization in an Indian Ocean Diaspora. Cambridge: Cambridge University Press.

Lee, S. and Thomas Kendall. 1820. Grammar and Vocabulary of the Language of New Zealand. London: Church Missionary Society.

Lissarrague, Amanda. 2006. A Salvage Grammar and Wordlist of the Language from the Hunter River and Lake Macquarie. Nambucca Heads, N.S.W.: Muurrbay Language and Culture Centre.

McDonald, Heather. 2001. Blood, Bones and Spirit: Aboriginal Christianity in an East Kimberley Town. Melbourne: Melbourne University Press.

McGregor, William B., ed. 2008a. Encountering Aboriginal Languages. Studies in the History of Australian Linguistics, Pacific Linguistics. Canberra: Research School of Pacific and Asian Studies, Australian National University.

McGregor, William B. 2008b. Missionary Linguistics in the Kimberley, Western Australia. Historiographia Linguistica 35: 121-62.

Mackaness, George, ed. 1965. Fourteen Voyages over the Blue Mountains of New South Wales, 1813-1841. Sydney: Horwitz-Grahame.

Oates, Lynette F. 1999. The Summer Institute of Linguistics and Aboriginal-Islander Research. Aboriginal History 23: 43-50.

Pennycook, Alistair. 1998. English and the Discourses of Colonialism. London: Routledge.

Peterson, Derek. 1999. Translating the Word: Dialogism and Debate in Two Gikuyu Dictionaries. Journal of Religious History 23, 1: 31-50.

Poole, Alison. 1988. Bibliography of the Summer Institute of Linguistics, Australian Aborigines and Islanders Branch, Up to December 1988. Darwin: Summer Institute of Linguistics Australian Aborigine and Island Branch.

Porter, Andrew N. 2004. Religion versus Empire? Manchester: Manchester University Press.

Prior, Michael. 1997. The Bible and Colonialism: A Moral Critique. Sheffield: Sheffield Academic Press. 
Rafael, Vicente L. 1988. Contracting Colonialism: Translation and Christian Conversion in Tagalog Society under Early Spanish Rule. Ithaca: Cornell University Press. Reynolds, Henry. 1998. This Whispering in Our Hearts. Sydney: Allen and Unwin.

Roberts, David A. 2002. Birabahn, or Johnny M'Gill (c. 1800-1846). In David Roberts, Hilary Carey, and, Vicki Grieves, eds., Awaba: A Database of Historical Materials Relating to the Aborigines of the Newcastle-Lake Macquarie Region. University of Newcastle. At: http://www.newcastle.edu.au/centre/awaba/awaba/group/amrhd/ awaba/people/birabahn.html.

Roberts, David A. 2008. "Language to Save the Innocent": Reverend L. Threlkeld's Linguistic Mission. Journal of the Royal Australian Historical Society 94, 2: 107-25.

Roberts, David A., Hilary M. Carey, and, Vicki Grieves, eds. 2002. Awaba: A Database of Historical Materials Relating to the Aborigines of the Newcastle-Lake Macquarie Region. University of Newcastle. At: http://www.newcastle.edu.au/group/amrhd/ awaba/.

Sanneh, Lamin. 1989. Translating the Message: The Missionary Impact on Culture. Maryknoll, N.Y.: Orbis.

Sanneh, Lamin. 2001. "They Stooped to Conquer": Cultural Vitality and the Narrative Impulse. In K. E. Yandell, ed., Faith and Narrative. Oxford: Oxford University Press, $15-52$.

Schmidt, Wilhelm. 1919. Die Gliederung Australischen Sprachen: Geographische, Bibliographische, Linguistische Grundzüge Der Erforschung Der Australischen Sprachen. Vienna: Druck und Verlag.

Smalley, William A. 1991. Translation as Mission: Bible Translation in the Modern Missionary Movement. Macon, Ga.: Mercer.

Smith, Edwin William. 1925. Robert Moffat: One of God's Gardeners. London: Student Christian Movement.

Stoll, D. 1982. Fishers of Men or Founders of Empire? The Wycliffe Bible Translators in Latin America. London: Zed.

Strehlow, Carl F. T. 1925. Ewangelia Lukaka (Gospel of St. Luke in the Aranda or Arunta Language). London: British and Foreign Bible Society.

Sugirtharajah, R. S. 2002. Postcolonial Criticism and Biblical Interpretation. Oxford: Oxford University Press.

Sugirtharajah, R. S, ed. 2005 The Bible and the Empire: Postcolonial Explorations. Cambridge: Cambridge University Press.

Swain, Tony. 1993. A Place for Strangers: Towards a History of Australian Aboriginal Being. Cambridge: Cambridge University Press.

Thorne, Susan. 1997. "The Conversion of Englishmen and the Conversion of the World Inseparable": Missionary Imperialism and the Language of Class in Early Industrial Britain. In Frederick Cooper and, Ann Laura Stoler, eds., Tensions of Empire. Berkeley: University of California Press.

Thorne, Susan. 1999. Congregational Missions and the Making of an Imperial Culture in Nineteenth-Century England. Stanford: Stanford University Press.

Thorne, Susan. 2006. Religion and Empire at Home. In Catherine Hall and Sonya Rose, eds., At Home with the Empire. Cambridge: Cambridge University Press.

Threlkeld, L. E. 1825. The Orthography and Orthoepy of a Dialect of the Aborigines of New South Wales. Sir Thomas Brisbane Papers, 1812-1837. Sydney, State Library of New South Wales, microfilm FM 4/1626.

Threlkeld, L. E. 1827. Specimens of a Dialect of the Aborigines of New South Wales, 1826. Sydney: n.p.

Threlkeld, L. E. 1828-1846. Threlkeld Journal. Private collection. Sydney, State Library of New South Wales, Sydney, microfilm FM4/ 6217. Digitized at: 
http://www.newcastle.edu.au/service/archives/aboriginalstudies/pdf/Threlkeld-Journalversion2.pdf.

Threlkeld, L. E. 1834a. An Australian Grammar Comprehending the Principles and Natural Rules of the Language as Spoken by the Aborigines in the Vicinity of Hunter's River, Lake Macquarie, New South Wales. Sydney: Stephens and Stokes, Herald Office. Repr. in John Fraser, ed., An Australian Language as Spoken by the Awabakal the People of Awaba or Lake Macquarie. Part I (A). Sydney: Government Printer, 1892.

Threlkeld, L. E. 1834b. A Selection of Prayers for the Aborigines of Australia, 1834. Sydney, State Library of New South Wales, Sydney, ML MSS A1446 [State Library of New South Wales microfilm CY 2214, fr.76-91]. Repr. in John Fraser, ed., An Australian Language as Spoken by the Awabakal the People of Awaba or Lake Macquarie. Part IV (E). Sydney: Government Printer, 1892.

Threlkeld, L. E. 1836. An Australian Spelling Book in the Language as Spoken by the Aborigines, in the Vicinity of Hunter's River, Lake Macquarie, New South Wales. Sydney: Stephens and Stokes, Herald Office.

Threlkeld, L. E. 1836-1841. Annual Reports of the Mission to the Aborigines, Lake Macquarie. In, Miscellaneous Correspondence Relating to Aborigines, State Records of New South Wales, 5/1161. Sydney: private printer. Repr. in Niel Gunson, ed., Australian Reminiscences and Papers of L. E. Threlkeld. 2 vols. Canberra: Australian Institute of Aboriginal Studies, 1974.

Threlkeld, L. E. 1837. Gospel of St. Mark [Evanelia Mark- ūmba]. Sydney, State Library of New South Wales, ML MSS 2111/2, fols. 255-73 [State Library of New South Wales microfilm CY 341, fr.723-935]. Digitised at: http://acms.sl.nsw.gov.au/ album/albumView.aspx?acmsID=825646\&itemID $=825621$.

Threlkeld, L. E. 1850. A Key to the Structure of the Aboriginal Language. Sydney: Kemp and Fairfax for the Royal National Exhibition, London, 1850. Repr. in John Fraser, ed., An Australian Language as Spoken by the Awabakal the People of Awaba or Lake Macquarie. Part I (A). Sydney: Government Printer, 1892.

Threlkeld, L. E. 1853. Reminiscences. In, The Christian Herald, and Record of Missionary and Religious Intelligence. Sydney, 26 Feb. 1853-28 April 1855. Repr. in Niel Gunson, ed., Australian Reminiscences and Papers of L. E. Threlkeld. 2 vols. Canberra: Australian Institute of Aboriginal Studies, 1974, 41-82.

Threlkeld, L. E. 1857. Gospel of St. Luke [Evangelion Unni ta Jesu-ūm-ba Christ-ko-ba Upatōara Louka-ūmba], 1831, rev. 1857. Auckland, Auckland Public Library, Grey MSS 82. Repr. in John Fraser, ed., An Australian Language as Spoken by the Awabakal the People of Awaba or Lake Macquarie. Part III. Sydney: Government Printer, 1892.

Threlkeld, L. E. 1858. Lexicon to Gospel of St. Luke, 1858. Auckland, Auckland Public Library, Grey MSS 83. Repr. in John Fraser, ed., An Australian Language as Spoken by the Awabakal the People of Awaba or Lake Macquarie. Part III. Sydney: Government Printer, 1892.

Threlkeld, L. E. 1997. Euangelion Unni Ta Jesu-Umba Christ-Ko-Ba Upatoara Luka-Umba. The Gospel of Jesus Christ According to Luke in Awabakal and English (R.S.V.). Ingleburn, N.S.W.: Bible Society in Australia.

Tindale, Norman Barnett. 1974. Aboriginal Tribes of Australia: Their Terrain, Environmental Controls, Distribution, Limits and Proper Names. Berkeley: University of California Press.

Tomlinson, Matt. 2006. Retheorizing Mana: Bible Translation and Discourse of Loss in Fiji. Oceania 76, 2: 173-85.

Tomlinson, Matt. 2009. Efficacy, Truth, and Silence: Language Ideologies in Fijian Christian Conversions. Comparative Studies in Society and History 51, 1: 64-90. 
van Toorn, Penny. 2006. Writing Never Arrives Naked: Early Aboriginal Cultures of Writing in Australia. Canberra: Aboriginal Studies Press.

Trigg, Stephanie, ed. 2005. Medievalism and the Gothic in Australian Culture. Melbourne: Melbourne University Press.

Walker, John. 1807. A Critical Pronouncing Dictionary. New York: Stansbury, Ronalds, Osborn and Hopkins.

Wilkes, Charles. 1845. Narrative of the United States Exploring Expedition. Vol. 2. Philadelphia: Lea and Blanchard.

Wolfe, Patrick. 1991. On Being Woken Up: The Dreamtime in Anthropology and in Australian Settler Culture. Comparative Studies in Society and History 33, 2: 197-224. 